\title{
Identity politics
}

\author{
Use of origins research for political point-scoring is depressingly frequent, but scientists must take what care they \\ can to ensure that their work is not abused.
}

$\mathrm{P}$ oliticians have always made use of the past to justify their claims to rule: Egyptian pharaohs built new tombs inside existing ones and reused coffins to exert legitimacy over their predecessors; incoming Anglo-Saxon elites re-used Roman cemeteries and prehistoric burial mounds to fix their origins in Britain. Our origins are important to us, but origin-building is a subjective game, and the scientific evidence is often abused in support of dubious claims. That this is not just by extremists on either end of the political spectrum is becoming increasingly obvious.

Israeli Prime Minister Benjamin Netanyahu recently approvingly tweeted the findings of a recent ancient DNA paper that suggested that the biblically known Philistines (famed for their enmity with the ancient Israelites) originated in Europe ${ }^{1}$. Archaeologists and geneticists alike flocked to condemn this act of nation-building based on a misinterpretation of genetic evidence. Such abuse, however, is not limited to the political right. Senator Elizabeth Warren, one of the Democratic presidential frontrunners ahead of the 2020 US elections, last year undertook a DNA test in response to Donald Trump's taunting of her frequent claim to Native American ancestry. The fact that the results indeed showed some genetic evidence of Native American ancestry is inconsequential because, as indigenous scholar Kim TallBear has pointed out, the idea that Native ancestry can be 'tested' at all relies on colonialist definitions, whereas "Native people's own notions of belonging, in addition to contentious but vital tribal political definitions of citizenship, emphasize lived social relations, both with human relatives and with our nonhuman relatives in our traditional lands and waters. Genetic ancestry alone is a shallow definition of who we are." Warren later apologized privately to a leader of the Cherokee Nation for causing confusion on tribal sovereignty and citizenship, but continues to be criticized for failing to make a more public apology.

Origins, identity and their politics are complex and relational, defined not only by our genes but also by place, time and society, among other factors. However, scientific research can often paint false pictures of objectivity and simplicity, particularly where the past is concerned. As the related but still-perhaps-too separate fields of archaeology and genetics grapple with the questions of who we are and where we came from, disciplinary naïveté can lead to misunderstanding, which can quickly spiral out of control beyond the immediate scientific community. In a recent article $^{2}$, archaeologist Susanne Hakenbeck notes that recent migration-centric narratives presented by ancient genomics research, while they benefit from cutting edge techniques and improved sampling power, have often failed to engage with the critical and nuanced ways in which archaeologists have developed thinking about ethnicity, gender and migrations over the past 100 years, driven in part by disciplinary awareness of what can happen when this discussion is not nuanced. If the use of culture history narratives by the Nazis and other extremists of the twentieth century is the archaeological skeleton in the epistemological cupboard, then surely modern genetics has its own in the form of eugenics: both disciplines have learned from their uncomfortable pasts, which they have confronted to varying degrees, but it is now time they learnt from each other's, facing the facts that racism has no scientific basis and that pots really do not equal people.

Humans are unlikely to lose interest in our origins, and uncovering who we are and where we have come from will always remain a vital question for us, both philosophically and scientifically. However, this widespread interest means that the communities working with these volatile contexts and questions have a duty of care to prevent, as far as possible, their findings being distorted for political aims. Institutions and journals need to take more care with press releases, avoiding the easy sensationalist narrative likely to make headlines. This is more easily achieved when balanced peer review introduces nuance, as does equitable collaboration from the get go. The power imbalance between colleagues in this area of research has been written about before - "Collaboration doesn't mean I send you an e-mail saying 'Hey, you've got some really cool bones. I'll get you a Nature paper." - but bears repeating. There is also a need to understand that frequently used terminology can be context dependent and potentially contentious: what do we mean when we talk about ethnicity, group, individual and population, and how heterogeneous are any of these entities? Both archaeologists and geneticists need to become more literate in each other's fields. Never has what's in a name become more important, and such definitions cannot be sidelined to Supplementary information or post-hoc discussion when the horse has already bolted. They should become a starting point for discussion and need to be included in press releases. Archaeologists and geneticists could also take care to use less loaded demonyms that are unlikely to inflame due to historical or derogatory connotations (such as Philistines or Barbarians), and that don't conflate artefact taxonomy or subsistence mode with genetic groups in a form of genetic culture history (for example, Beaker people), though they may disagree about the best strategy ${ }^{3}$.

In her new book exploring the return of race science, Angela Saini notes that "factual nuggets", rather than coherent scientific frameworks are what fuel racist speculation (she reminds us of the white supremacists who flaunt their milk moustaches, so misguidedly proud are they of their lactase persistence) and that "science is always shaped by the time and place in which it is carried out". In other words, we and our science exist in a societal feedback loop. We have the ability to shape science, but if we do not take care in its publication and dissemination, we may find the darker edges of society's framework coming back to haunt us.

Published online: 24 July 2019

https://doi.org/10.1038/s41559-019-0961-8

\footnotetext{
References

1. Feldman, M. et al. Sci. Adv. 5, eaax0061 (2019).

2. Hakenbeck, S. World Archaeol. https://doi.org/10.1080/00438243. 2019.1617189 (2019).

3. Eisenmann, S. et al. Sci. Rep. 8, 13003 (2018).

4. Saini, A. Superior: The Return of Race Science (4th Estate, 2019).
} 